\title{
Mortality from respiratory infections and chronic non-communicable diseases before the COVID-19 pandemic in Cali, Colombia
}

\section{Mortalidad por infecciones respiratorias y enfermedades crónicas no trasmisibles antes de la pandemia por COVID-19 en Cali, Colombia}

\author{
Luis Eduardo Bravo ${ }^{1,2}$ Paola Collazos $^{1}{ }^{D}$, Elvia Karina Grillo Ardila ${ }^{1,4}{ }^{6}$, Luz Stella \\ García $^{1}$ Erquinovaldo Millan ${ }^{5}$, Patricia Mera ${ }^{5}$, Jorge Holguín ${ }^{5}$ \\ luis.bravo@correounivalle.edu.co
}

1 Registro Poblacional de Cáncer de Cali. Cali, Colombia. 2 Universidad del Valle, Facultad de Salud, Departamento de Patología, Cali, Colombia. 3.Universidad del Valle, Facultad de Salud, Departamento de Patología, Cali, Colombia. 4 Universidad del Valle, Facultad de Salud, Doctorado en Salud. Cali, Colombia. 5 Secretaria de Salud Pública Municipal de Cali, Cali, Colombia

\section{OPPEN ACCESS}

Citation: Bravo LE, Collazos P, Grillo AEK, García LS, Millan E, Mera P, Holguín J. Colomb Med (Cali). 2020; 51(2):e-4270. http://doi. org/10.25100/cm.v51i2.4270

Received : 02 Apr 2020

Revised : 25 Apr 2020

Accepted : 04 May 2020

Published: 11 May 2020

Keywords:

COVID-19, chronic diseases, mortality from respiratory infections

Palabras clave:

COVID-19, enfermedades crónicas, mortalidad por infecciones respiratorias

Copyright: $\odot$ 2020. Universidad del Valle.

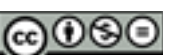

\section{Abstract}

\section{Introduction:}

The COVID-19 disease pandemic is a health emergency. Older people and those with chronic noncommunicable diseases are more likely to develop serious illnesses, require ventilatory support, and die from complications.

\section{Objective:}

To establish deaths from respiratory infections and some chronic non-communicable diseases that occurred in Cali, before the SARS-CoV-2 disease pandemic.

\section{Methods:}

During the 2003-2019 period, 207,261 deaths were registered according to the general mortality database of the Municipal Secretary of Health of Cali. Deaths were coded with the International Classification of Diseases and causes of death were grouped according to WHO guidelines. Rates were standardized by age and are expressed per 100,000 people-year.

\section{Results:}

A direct relationship was observed between aging and mortality from respiratory infections and chronic non-communicable diseases. Age-specific mortality rates were highest in those older than 80 years for all diseases evaluated. Seasonal variation was evident in respiratory diseases in the elderly.

\section{Comments:}

Estimates of mortality rates from respiratory infections and chronic noncommunicable diseases in Cali provide the baseline that will serve as a comparison to estimate the excess mortality caused by the COVID-19 pandemic. Health authorities and decision makers should be guided by reliable estimates of mortality and of the proportion of infected people who die from SARS-CoV-2 virus infection. 


\section{Conflict of interest:}

None

\section{Funding:}

This investigation was financed by Universidad del Valle and partially by Univalle-Vandervilt University-NIH-USA (Prime Award No.2 P01 CA028842, Subaward No. VUMC3239) enrolled in the Universidad del Valle Information Centre: 1641.

\section{Corresponding author:}

Luis Eduardo Bravo, Director Registro Poblacional de Cáncer de Cali. Calle 4B 36-00 Edificio 116 Oficina 4009, Cali, Colombia. E-mail: luis.bravo@ correounivalle.edu.co

\section{Remark}

\section{Why was this study conducted?}

To provide a robust baseline of the number of deaths that occurred in Cali, prior to the SARS CoV-2 pandemic caused by respiratory infections diseases and some chronic non-communicable diseases (respiratory diseases, cardiovascular diseases, cancer, and diabetes mellitus). It allows estimating the excess of mortality caused by the SARS-CoV-2/COVID-19 pandemic

\section{What were the most relevant results of the study?}

Noncommunicable chronic diseases caused $76 \%$ of the 65,906 deaths that occurred in Cali during the five-year period 2015-2019;22\% of these deaths were caused by cancer. In respiratory diseases, a more evident seasonal variation was observed in the elderly.

\section{What do these results contribute?}

A method that can be used in other regions or cities. Knowing the mortality rates, their temporal trend and the frequency distribution of deaths in Cali before the pandemic, will allow modeling excess mortality to determine the real impact of the SARS-CoV-2/COVID-19 pandemic.

\section{Resumen}

\section{Introducción:}

La pandemia de la enfermedad COVID-19 es una emergencia sanitaria. Las personas mayores y aquellos con enfermedades crónicas no trasmisibles tienen más probabilidades de desarrollar enfermedades graves, requerir soporte ventilatorio y morir a causa de las complicaciones.

\section{Objetivo:}

Establecer las defunciones por infecciones respiratorias y por algunas enfermedades crónicas no trasmisibles ocurridas en Cali, antes de la pandemia de la enfermedad por el SARS-CoV-2.

\section{Métodos:}

Durante el periodo 2003-2019, se registraron 207,261 defunciones información obtenida de la base de datos de mortalidad general de la Secretaria de Salud Municipal de Cali. Las defunciones se codificaron con la Clasificación Internacional de Enfermedades y las causas de muerte se agruparon según las guías de la OMS. Las tasas se estandarizaron por edad, son expresadas por 100,000 personas-año.

\section{Resultados:}

Se observó una relación directa entre envejecimiento y la mortalidad por infecciones respiratorias y enfermedades crónicas no trasmisibles. Las tasas de mortalidad específicas por edad fueron más altas en los mayores de 80 años para todas las enfermedades evaluadas. En las enfermedades respiratorias fue evidente una variación estacional en los ancianos.

\section{Comentario:}

Las estimaciones de las tasas de mortalidad por infecciones respiratorias y enfermedades crónicas no trasmisibles para Cali proporcionan la línea de base que servirá de comparación para estimar el exceso de mortalidad que ocasionará la pandemia de COVID-19. Las autoridades sanitarias y los tomadores de decisiones deben guiarse por estimaciones fiables de la mortalidad y de la proporción de infectados que mueren por la infección del virus SARSCoV-2. 


\section{Introduction}

The COVID-19 disease pandemic is a global health emergency caused by severe acute respiratory syndrome coronavirus 2 (SARS-CoV-2). The first human case of this disease occurred in late 2019 and in four months it spread to almost every country in the world ${ }^{1,2}$.

The majority of the COVID-19 infected population experiences mild to moderate respiratory disease and recovers without requiring special treatment. Older people and those with underlying medical problems such as chronic non-communicable diseases (cardiovascular, diabetes, chronic respiratory diseases, and cancer) are more likely to develop serious diseases, require ventilatory support, and die from complications ${ }^{3-7}$.

The actual number of deaths from SARS-CoV-2/COVID19 is underestimated because hospitals, medical providers, and health authorities are reporting only confirmed cases. The effective number of deaths caused by the SARS-CoV-2 virus will only be evident after statistically modelling excess mortality during the period that this pandemic last.

Through collaborative inter-institutional work between the Municipal Public Health Secretary, the Hospital Registries of Cali, the epidemiological surveillance system for childhood cancer VIGICANCER and the Population Cancer Registry of Cali, the behavior of cancer patients will be monitored to see the impact of the COVID-19 pandemic. The objective is to establish the baseline to calculate excess mortality during the SARS-Cov-2 pandemic. The method can be used in other regions or cities that have registries and observatories of chronic noncommunicable diseases and cancer.

\section{Materials and Methods}

Cali is the capital of Valle del Cauca Department and the third largest city in Colombia. According to the 2018 census and according to DANE projections, the estimated population for 2023 is 2.3 million inhabitants of which $54 \%$ will be women ${ }^{8,9}$. Of the total population of Cali, $26.2 \%$ recognize themselves as belonging to the black ethnic group ${ }^{10}$. Life expectancy at birth is 74.4 years old ${ }^{11}$ with gender distribution of 82.7 for women and 77.4 for men ${ }^{12}$. The infrastructure for cancer care has 165 authorized cancer services ${ }^{13}$. These services are found in the urban area where $95 \%$ of the population lives. That population lives in an area of $110 \mathrm{~km}^{2}$, which corresponds to $20 \%$ of the extension of the municipality of Cali $\left(503 \mathrm{~km}^{2}\right)$.

Information on the number of deaths, by basic cause from January 2003 to February 2020, was obtained from the general mortality database of the Municipal Health Secretariat of Santiago de Cali. The methods for its epidemiological registration have been previously described ${ }^{10,14}$. The International Classification of Diseases (ICD-10) ${ }^{15}$ was used to code deaths, and following the guidelines of the World Health Organization (WHO) ${ }^{16)}$ the causes of death were grouped into three major groups of diseases: communicable, chronic, non-communicable and injuries; the rubrics of each category are detailed in Table 1.

Deaths from respiratory infections and chronic non-communicable diseases associated with fatal outcome during the COVID-19 pandemic (malignancies, diabetes mellitus, and cardiovascular and respiratory diseases) were included in the analysis. The structure of the population by five-year age groups for each calendar year was obtained from the National Administrative Department of Statistics of Colombia (DANE) ${ }^{17}$. Mortality rates for the entire population were age-standardized (ASR) by the direct method using the world standard population as a reference. Global and age-specific rates are expressed per 100,000 people-years. The trend in mortality rates between 2003 and 2009 was described using the Annual Percent Change (APC), calculated using the weighted least squares method ${ }^{18}$. To detect seasonal changes, monthly mortality rates were estimated during the 206 months evaluated (January 2003 to February 2020). 
Table 1. Abbreviated list of basic cause of death using Global Health Estimation (GHE) categories and ICD-10 codes

\begin{tabular}{|c|c|c|}
\hline GHE code & GHE Name cause & ICD-10 code \\
\hline 10 & $\begin{array}{l}\text { I. Communicable, maternal, perinatal and } \\
\text { nutritional conditions }\end{array}$ & $\begin{array}{l}\text { A00-B99, D50-D53, D64.9, E00-E02, E40-E46, } \\
\text { E50-E64, G00-G04, G14, H65-H66, J00-J22, N70-N73, } \\
\text { O00-0-99, P00-P96, U04 }\end{array}$ \\
\hline 380 & B. Respiratory infectious & H65-H66, J00-J22, P23, U04 \\
\hline 600 & II. Non-communicable diseases & $\begin{array}{l}\text { C00-C97, D00-D48, D55-D64 (menos D 64.9), } \\
\text { D65-D89, E03-E07, E10-E34, E65-E88, F01-F99, } \\
\text { G06-G98 (menos G14),H00-H61, H68-H93, I00-I99, } \\
\text { J30-J98, K00-K92, L00-L98, M00-M99, N00-N64, } \\
\text { N75-N98, Q00-Q99, X41-X42, X44,X45, R95 }\end{array}$ \\
\hline 610 & A. Malignant neoplasms & $\mathrm{C} 00-\mathrm{C} 97$ \\
\hline 800 & C. Diabetes mellitus & $\begin{array}{l}\text { E10-E14 (minus E10.2-E10.29, E11.2-E11.29, E12.2, } \\
\text { E13.2-E13.29, E14.2) }\end{array}$ \\
\hline 1100 & H. Cardiovascular diseases & I00-I99 \\
\hline 1170 & I. Respiratory diseases & J30-J98 \\
\hline 1510 & III. Injuries & V01-Y89 (minus X41-X42, X44, X45) \\
\hline 1520 & A. Unintentional injuries & V01-X40, X43, X46-59, Y40-Y86, Y88, Y89 \\
\hline 1600 & B. Intentional injuries & X60-Y09, Y35-Y36, Y870, Y87 \\
\hline
\end{tabular}

Source: WHO methods and data sources for country-level causes of death 2000-2015. Global Health Estimates, Department of Information, Evidence and Research, January 2017. WHO, Geneva Technical Paper WHO/HIS/IER/GHE/2016.3 ${ }^{16}$

\section{Results}

During the period 2003-2019 there were 207,261 deaths and 65,906 in the five-year period 2015-2019, with the following distribution of frequencies: Communicable diseases (7,249; $11.0 \%)$, chronic non-communicable diseases $(50,121 ; 76.0 \%)$, and injuries $(8,536 ; 13.0$ $\%)$. For the diseases included in the analysis, the frequency distribution was as follows: Respiratory infections $(6.1 \%)$, respiratory diseases $(5.4 \%)$, cancer $(22.3 \%)$, diabetes $(2.6 \%)$ and cardiovascular disease (30.1\%).

The average annual mortality rate per 100,000 people-year for all causes of death was higher among men (568) than among women (322). Excess mortality could be explained by chronic non-communicable diseases such as malignant neoplasms and cardiovascular diseases, and by intentional injuries (Table 2).

The mortality rates from chronic non-communicable diseases in the five-year period (20152019) were like those in 2019 (Table 4-Suppl); however, mortality rates from communicable diseases and injuries were lower in 2019 compared to those observed in the five-year period (2015-2019) (Table 2).

Figure 1 shows that the risk of dying is directly associated with aging and that mortality rates from cardiovascular diseases remained stable in people older than 65 years old. In contrast, a significant decrease in the risk of dying was observed between 2003 and 2019 among those younger than 65 and in all age groups, related to respiratory diseases and diabetes mellitus. The magnitude of the decrease was greater in the group of 50-64 years old. Influenza and pneumonia death rates decreased significantly in children younger than 5 years old and remained stable in the other age groups.

APC: Annual Percent; CI: 95\% confidence interval during the study period (17 years). ${ }^{\star}$ APC is significantly different from zero $(0)$

Figure 2 shows the temporal variation of the monthly age-specific mortality rates for the respiratory diseases group and the monthly variations of the global rates for the cardiovascular disease, cancer and diabetes mellitus groups. Age-specific rates were highest in those older than 80 years for all diseases evaluated. In the group of respiratory diseases, influenza and pneumonia, there was more evident seasonal variation in the elderly and with few exceptions, the peaks occurred between the months of October and January. 
Table 2. Cali, Colombia. Mortality rates per 100,000 people-year, by sex and basic cause of death during the 2015-2019 period.

\begin{tabular}{|c|c|c|c|c|c|c|c|c|c|}
\hline \multirow{2}{*}{ Cause of death } & \multicolumn{3}{|c|}{ Both } & \multicolumn{3}{|c|}{ Men } & \multicolumn{3}{|c|}{ Women } \\
\hline & Rate & $\mathbf{n}$ & $\%$ & Rate & $\mathbf{n}$ & $\%$ & Rate & $\mathbf{n}$ & $\%$ \\
\hline I. Communicable, maternal, perinatal and nutritional conditions & 50.4 & 7,249 & 11.0 & 66.7 & 3,957 & 11.2 & 37.8 & 3,292 & 10.8 \\
\hline Respiratory infectious & 24.6 & 3,994 & & 31.2 & 1,967 & & 20.0 & 2,027 & \\
\hline Others & 25.8 & 3,255 & & 35.5 & 1,990 & & 17.8 & 1,265 & \\
\hline II. Non-communicable diseases & 312.9 & 50,121 & 76.0 & 380.8 & 24,007 & 68.0 & 268.0 & 26,114 & 85.4 \\
\hline Malignant neoplasms & 96.7 & 14,681 & & 110.8 & 6,904 & & 88.5 & 7,777 & \\
\hline Mellitus diabetes & 10.8 & 1,712 & & 12.8 & 810 & & 9.3 & 902 & \\
\hline Cardiovascular diseases & 118.0 & 19,821 & & 150.0 & 9,608 & & 95.8 & 102,133 & \\
\hline Respiratory diseases & 20.4 & 3,588 & & 27.4 & 1,776 & & 15.9 & 1,812 & \\
\hline Others & 67.0 & 6,325 & & 79.8 & 4,909 & & 58.5 & 3,303 & \\
\hline III. Injuries & 66.7 & 8,536 & 13.0 & 121.1 & 7,350 & 20.8 & 16.3 & 1,186 & 3.9 \\
\hline Unintentional injuries & 19.7 & 2,706 & & 32.3 & 1,969 & & 9.2 & 737 & \\
\hline Intentional injuries & 47.0 & 5,830 & & 88.9 & 5,381 & & 7.0 & 449 & \\
\hline Total & 429.6 & 65,906 & & 568 & 35,314 & & 322 & 30,592 & \\
\hline
\end{tabular}

Source: WHO methods and data sources for country-level causes of death 2000-2015. Global Health Estimates, Department of Information, Evidence and Research, January 2017. WHO, Geneva Technical Paper WHO/HIS/IER/GHE/2016.3 ${ }^{16}$

\section{Discussion}

Estimates of the magnitude and temporal trend of mortality rates from respiratory infections and chronic non-communicable diseases for the entire population of Cali over three fiveyear periods, provide a robust baseline that will serve as a comparison to estimate the excess mortality caused by COVID-19 pandemic. Seasonal variations in mortality were evident in the group of older adults suggesting that this section of the population bears the heaviest burden in terms of the severity of seasonal influenza. Patients suffering from COVID-19 that have the highest risk of death are those of advanced age and with the presence of pre-existing conditions such as diabetes mellitus, cardiovascular diseases, cancer, hypertension and smoking. The impact of the disease on them can be measured by the case fatality rate (CFR) ${ }^{19}$.

Properly classifying the causes of death during the COVID-19 pandemic is an emerging challenge. It is imperative that health authorities and decision makers be guided by reliable estimates of mortality and IFC. This index measures the proportion of infected people who die from SARS-CoV-2 virus infection. An accurate count of the number of deaths due to COVID-19 depends in part on proper completion of the death certificate ${ }^{20}$. When a patient suffering from COVID-19 dies, it is likely that this disease is the basic cause of death, even in patients with comorbidities such as chronic, non-communicable diseases, which are contributing causes, but are not part of the causal sequence.

The COVID-19 CFR shows the pattern of an emerging infectious disease. At the beginning of the disease and when first cases are described, CFR is high and then decreases as the pandemic progresses. The denominator of the CFR in the COVID-19 pandemic is variable and closely related to the control policies implemented by regional and/or national health authorities ${ }^{19}$. A major challenge in accurately calculating IFC is the denominator: the number of people infected with the virus. Asymptomatic cases of COVID-19, patients with mild symptoms, or individuals misdiagnosed (false negatives) could be left out of the denominator, leading to underestimation of the number of infected and an overestimation of CFR ${ }^{19}$.

CFR depends on the number of tests performed to detect people with COVID-19 disease. The countries that achieved control of the pandemic have a higher denominator and a lower CFR because at the beginning of the pandemic they invested resources in mass analysis with intensive tracing of cases and tests on contacts, without limiting themselves to seriously ill patients. Their proposals included the implementation of extreme social isolation, localized quarantines, and follow-up monitoring of suspected cases, even in vulnerable populations, 


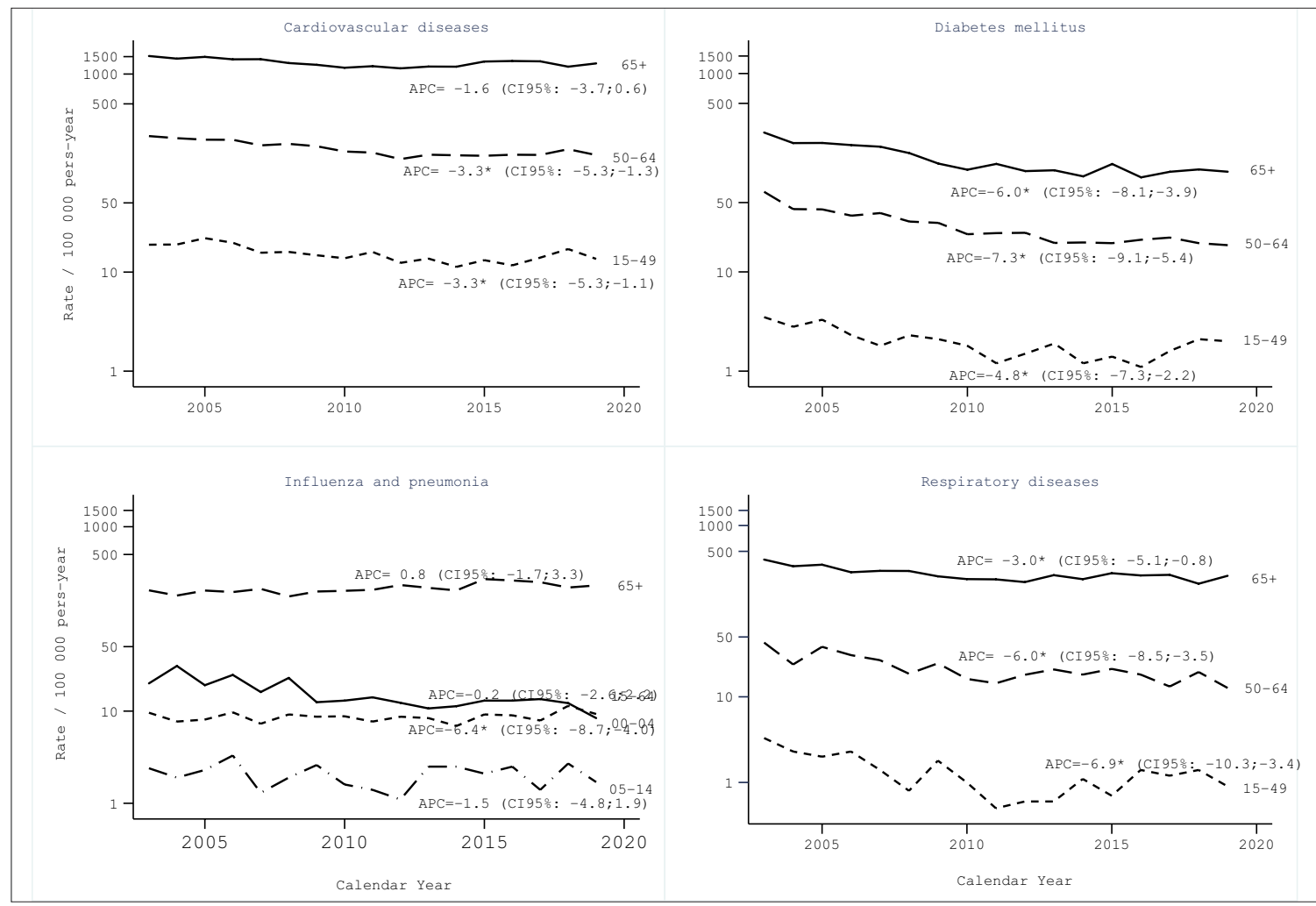

Figure 1. Cali, Colombia. Trend in age-specific mortality rates for some selected categories during the period 2003-2019. Mortality rates are expressed per 100,000 people per year. ${ }^{\star}$ APC Annual Percent; CI: $95 \%$ confidence interval during the study period (17 years). ${ }^{*}$ APC is significantly different from zero $(0)$

to contain the spread. In contrast, countries that did not exercise control measures for the pandemic have a lower denominator and a high CFR because in the presence of dozens of infections and multiple possible asymptomatic cases, confirmatory laboratory tests for the virus were reserved for patients with severe symptoms ${ }^{20}$. The lack of opportunity in the implementation of containment measures led these countries and cities to a collapse in health services due to the avalanche of critical cases, the inadequate operation of local laboratories, damming of samples, and a shortage of mechanical ventilators and health personal. In addition, they have also demonstrated a lack of diagnostic capacity that has made it impossible to truly know the dimension and impact of the disease.

The national percentage of duly certified deaths in Colombia is $93.7 \%$ (21. To guarantee the validity of the estimates of excess mortality caused by COVID-19, it is a priority to standardize the basic cause of death during the pandemic. The WHO used the international disease classification (IDC) and assigned emergency headings U07.1 and U07.2 to deaths from SARS$\mathrm{CoV}-2$ infection confirmed by laboratory and clinically and epidemiologically diagnosed, respectively. Codes U00-U49 are used by WHO for the provisional allocation of new diseases of uncertain aetiology. In emergency situations, codes are not always accessible in electronic systems. Specification of category U07 in the manner in which it is done in Table 3 will ensure that this category and its subcategories are available in all electronic systems at any time and that they can be used immediately according to WHO instructions ${ }^{22}$.

The collapse of health systems and even funeral services and the fear of becoming ill can contribute to all deaths occurring outside the hospital setting, as well as that of any symptomatic respiratory patient without confirmatory test, being directly attributed to SARSCov-2/COVID-19. This current problem facilitates the production of cases of poor classification when registering the causes of death in death certificates. This will cause a trend that may suggest a false decrease in mortality rates attributable to chronic non-communicable diseases, specifically those related to cancer. 


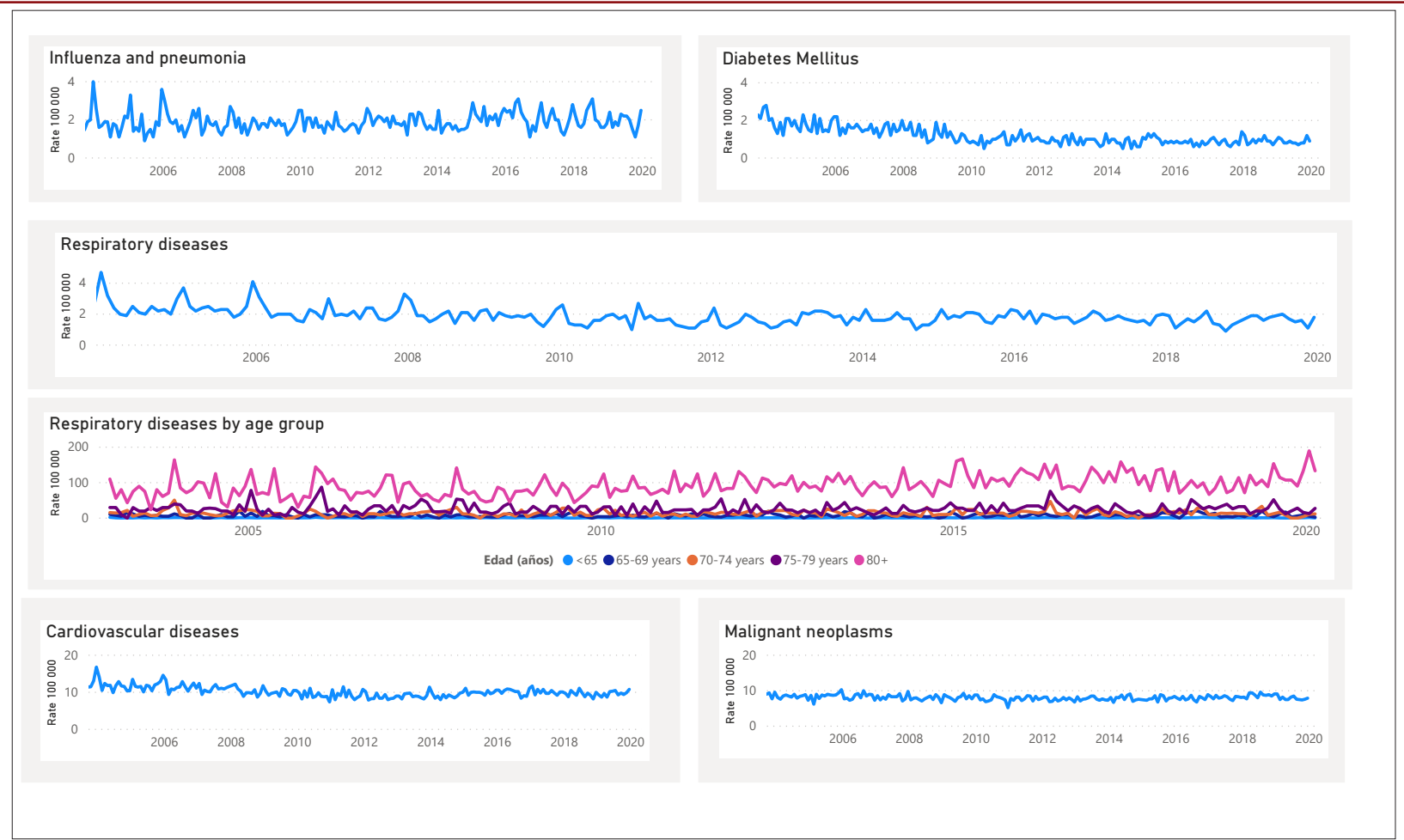

Figure 2. Cali, Colombia. Changes in monthly general and age-specific mortality rates for respiratory infections and selected chronic noncommunicable diseases between January 2003 and February 2020. In deaths from respiratory diseases (influenza and pneumonia), the monthly mortality rates per 100,000 people-year show seasonal variation and with few exceptions, the peaks occurred between October and January.

\section{Comments}

The massification of diagnostic tests, the reduction in response time and the mapping of serious respiratory infections are the main strategies used by developed countries to slow down the spread of the disease. In countries where hundreds of deaths are recorded daily, where there are no diagnostic tests, and in those where the fear of being infected is greater, it is impossible for health sectors to accurately diagnose the cause of death.

Knowing the mortality rates, their time trend and the frequency distribution of deaths in Cali before the pandemic, will allow modelling excess mortality to determine the real impact of the disease.

\section{Referencias}

1. Lu H, Stratton CW, Tang YW. Outbreak of pneumonia of unknown etiology in Wuhan, China: The mystery and the miracle. J Med Virol. 2020;92(4):401-2.

2. Chen N, Zhou M, Dong X, Qu J, Gong F, Han Y, et al. Epidemiological and clinical characteristics of 99 cases of 2019 novel coronavirus pneumonia in Wuhan, China: a descriptive study. Lancet. 2020;395(10223):507-13. Doi: 10.1016/S0140-6736(20)30211-7

3. Shankar A, Saini D, Roy S, Mosavi Jarrahi A, Chakraborty A, Bharti SJ, et al. Cancer Care Delivery Challenges Amidst Coronavirus Disease - 19 (COVID-19) Outbreak: Specific Precautions for Cancer Patients and Cancer Care Providers to Prevent Spread. Asian Pacific J Cancer Prev. 2020;21(3):569-73.

4. Liang W, Guan W, Chen R, Wang W, Li J, Xu K, et al. Cancer patients in SARS-CoV-2 infection: a nationwide analysis in China. Lancet Oncol. 2020;21(3):335-7.

5. CDC COVID-19 Response Team. Preliminary Estimates of the Prevalence of Selected Underlying Health Conditions Among Patients with Coronavirus Disease 2019 - United States, February 12-March 28, 2020. MMWR Morb Mortal Wkly Rep. 2020;69(13):382-6. 
Table 3. World Health Organization (WHO). Rubrics added to the International Classification of Diseases. ICD-10 for suspected cases of COVID-19. March 2020.

Instruction

Add exclusion Notes
Entries to the tabular list

B34.2 Coronavirus infection, site unspecified Excludes:

COVID-19, with virus identification (U07.1)

COVID-19, without virus identification (U07.2)

U04.9 Severe acute respiratory syndrome (SARS), unspecified Excludes:

COVID-19, with virus identification (U07.1)

COVID-19, without virus identification (U07.2)

U07.0

U07.1 COVID-19, identified virus Use this code when the virus has been identified by laboratory tests,

regardless of the severity of clinical signs and symptoms. Excludes: Coronavirus infection, site unspecified

Severe acute respiratory syndrome (SARS), unspecified (U04.9)

U07.2 COVID-19, unidentified virus

Use this code when the diagnosis of COVID-19 is clinical or epidemiological and the diagnostic test is inconclusive or unavailable.

COVID-19 NOS

Source: WHO, codification of COVID-19 with ICD-10, $2020^{22}$

6. Fang L, Karakiulakis G, Roth M. Are patients with hypertension and diabetes mellitus at increased risk for COVID-19 infection? Lancet Respir Med. 2020;2600(20):30116. Doi: 10.1016/S2213-2600(20)30116-8

7. Ministerio de Salud y Protección. Personas con diabetes, hipertensión y otras enfermedades de base deben quedarse en casa; 2020.. p. 3305050.

8. DANE. Censo Nacional de Población y censo nacional de vivienda. DANE; 2018. Available from: https:// www.dane.gov.co/index.php/estadisticas-por-tema/demografia-y-poblacion/censo-nacional-de-poblacion-yvivenda-2018/cuantos-somos

9. Mesa G. A. Proyecciones de población 2018-2023. DANE. 1985;(4):25-34.

10. Bravo LE, Collazos T, Collazos P, García LS, Correa P. Trends of cancer incidence and mortality in Cali, Colombia. 50 years experience. Colomb Med (Cali). 2012;43:246-55.

11. Organización Panamericana de la Salud. Salud en las Américas. Resumen: panorama regional y perfiles de país. 2017. 2017. 260 p. Available from: https:/www.paho.org/salud-en-las-americas-2017/wp-content/ uploads/2017/09/Print-Version-Spanish.pdf

12. Dicker D, Nguyen G, Abate D, Abate KH, Abay SM, Abbafati C, et al. Global, regional, and national age-sexspecific mortality and life expectancy, 1950-2017: A systematic analysis for the Global Burden of Disease Study 2017. Lancet. 2018;392(10159):1684-735.

13. Suarez A, Aguilera J, Salguero EA, Wiesner C. Pediatric oncology services in Colombia. Colomb Med (Cali). 2018;49(1):97-101.

14. Correa P, Llanos G. Morbidity and mortality from cancer in cali, colombia. J Natl Cancer Inst. 1966;36(4):717-45.

15. Ministerio de Sanidad Servicios Sociales e Igualdad. Clasificación Internacional de Enfermedades. 10a Revisión. Modificación Clínica. CIE-10-ES. Edición Española; 2018. 1-1492 p. Available from: https://bit.ly/2TxNGvt

16. Department of Information, Evidence and Research WHO. WHO methods and data sources for country-level causes of death 2000-2015 Global Health Estimates Technical Paper WHO/HIS/IER/ GHE/2016.3. Genove: World Health Organization. 2017. 1-81 p. Available from: http://www.ncbi.nlm.nih.gov/ pubmed/25378742\%5Cnhttp://www.pubmedcentral.nih.gov/articlerender.fcgi?artid=PMC4221770

17. DANE. Departamento Administrativo Nacional de Estadística Dirección de Censos y Demografía - DCD Coordinación de Demografía Ficha Técnica Revisión y Actualización de las Estimaciones y Proyecciones 
de Población período 1985-2020. 2010; Available from: https://www.dane.gov.co/files/investigaciones/fichas/ Ficha_Estimaciones_Proyecciones_85_2020.pdf

18. García LS, Bravo LE, Collazos P, Ramírez O, Carrascal E, Nuñez M, et al. Cancer Registration in Cali, Colombia. Colomb Med (Cali). 2018; 49(1): 109-120

19. Blazynska-Spychalska A, Kobiela J. Estimating case fatality rates of COVID-19. Lancet Infect Dis. 2020;(20):1-2. Doi: 10.1016/S1473-3099(20)30246-2

20. Wu JT, Leung K, Bushman M, Kishore N, Niehus R, de Salazar PM, et al. Estimating clinical severity of COVID-19 from the transmission dynamics in Wuhan, China. Nat Med. 2020; doi: 10.1038/s41591-020-0822-7

21. Cendales R, Pardo C. Quality of death certification in Colombia. Colomb Med (Cali). 2018;49(1):121-7.

22. OMS. Codificación del COVID-19 con la CIE-10. 2020. Disponible en: https://www.paho.org/arg/index. php?option=com_docman\&view=download\&alias=468-covid-cie-codigos-2020-03-25-espanol\&category_ slug=documentos $\&$ Itemid $=624$ 


\section{Anexo 1.}

Table 4. Cali, Colombia. Número de muertes, distribución de frecuencias y tasas de mortalidad estandarizadas por edad según sexo, 2019

\begin{tabular}{|c|c|c|c|c|c|c|c|c|c|}
\hline \multirow{2}{*}{ Causes of death } & \multicolumn{3}{|c|}{ Both } & \multicolumn{3}{|c|}{ Male } & \multicolumn{3}{|c|}{ Female } \\
\hline & Rate* & $\mathbf{n}$ & $\%$ & Rate* & $\mathbf{n}$ & $\%$ & Rate* & $\mathbf{n}$ & $\%$ \\
\hline I. Communicable, maternal, perinatal and nutritional condition & 44.0 & 1,392 & 10.1 & 59.7 & 770 & 10.5 & 32.2 & 622 & 9.7 \\
\hline Respiratory infections & 23.3 & 793 & & 29.7 & 391 & & 19.2 & 402 & \\
\hline Other & 20.7 & 599 & & 30.0 & 379 & & 13.0 & 220 & \\
\hline II. Noncommunicable diseases & 312.9 & 10,676 & 77.8 & 388.7 & 5,140 & 70.2 & 265.7 & 5,536 & 86.7 \\
\hline Malignant neoplasms & 94.6 & 3,097 & & 107.5 & 1,422 & & 87.7 & 1,675 & \\
\hline Diabetes mellitus & 10.6 & 357 & & 13.8 & 182 & & 8.5 & 175 & \\
\hline Cardiovascular diseases & 120.4 & 4,251 & & 158.4 & 2,106 & & 95.4 & 2,145 & \\
\hline Respiratory diseases & 20.4 & 756 & & 27.7 & 371 & & 15.8 & 385 & \\
\hline Other & 66.9 & 2,215 & & 81.3 & 1,059 & & 58.3 & 1,156 & \\
\hline II. Injuries & 59.9 & 1,648 & 12.0 & 108.3 & 1,417 & 19.3 & 14.8 & 231 & 3 \\
\hline Unintentional injuries & 18.0 & 529 & & 29.6 & 384 & & 8.7 & 145 & \\
\hline Intentional injuries & 41.8 & 1,119 & & 78.8 & 1,033 & & 6.2 & 86 & \\
\hline Total & 415.9 & 13,716 & 100.0 & 555.4 & 7,327 & 100.0 & 312.2 & 6,389 & 100. \\
\hline
\end{tabular}

Fuente: Secretaria de Salud Publica Municipal de Santiago de Cali

Tasas expresadas por 100,000 personas-año

La tasa de mortalidad estandarizada por edad es un promedio ponderado de la tasa de mortalidad edad especifica por 100,000 personas, donde los pesos son las proporciones de las personas en el correspondiente grupo de edad de la población estándar Segui 